\title{
Isolation and activation of collagenase from fish processing
} waste

\author{
Said M. Daboor, Suzanne M. Budge, Abdel E. Ghaly ${ }^{*}$, Marianne S. Brooks, Deepika Dave
}

Department of Process Engineering and Applied Science, Faculty of Engineering, Dalhousie University, Halifax, Canada Email: ${ }^{*}$ abdel.ghaly@dal.ca

Received 4 February 2012; revised 20 March 2012; accepted 9 April 2012

\begin{abstract}
Collagenase was isolated from fish waste (a mixture of haddock, herring, ground fish and flounder) using a Tris-buffer system. The proteins in the crude extract were precipitated using ammonium sulfate (40\% - 80\%) and purified with gel-filtration chromatography using Sephadex G-100. The results showed that the collagenase enzyme was produced as a latent enzyme and was activated with bovine trypsin and potassium thiocyanate (KSCN). The enzyme activity was affected by $\mathrm{pH}$ and temperature. Optimal enzyme activities were found at $35^{\circ} \mathrm{C}$ and a $\mathrm{pH}$ of 7.5 when insoluble collagene type $\mathrm{I}$ was used as substrate and the liberated amino acids were measured in relation to L-leucine in the presence of ninhydrin. The enzyme activity was completely inhibited by the action of ethylenediaminetetraacetic acid (EDTA) suggesting that the collagenase enzyme isolated from the fish waste is a metalloproteinase enzyme requiring metal ions for enzyme activity. Dialysis against KSCN decreased the enzyme total activity and increased its specific activity. Sodium dodecyl sulphate polyacrylamide gel electrophoresis (SDS-PAGE) indicated that the purified procollagenase enzyme have only one band at molecular weight of 50 kilodaltons (kDa). When the enzyme was cleaved with trypsin, it was found to consist of two subunits: a large unit with a molecular weight of $50 \mathrm{kDa}$ and a small unit with a molecular weight of $10 \mathrm{kDa}$.
\end{abstract}

Keywords: Fish Waste; Collagenase Enzyme; Extraction; Purification; Inhibitors; Activators

\section{INTRODUCTION}

Enzymes offer industrial processes with many advantages over chemical techniques. They allow for a better control of the production processes, are environmentally friendly (biodegradable), safe, easy to use and effective in low concentrations $[1,2]$. Proteases enzymes that catalyze the

*Corresponding author. hydrolysis process of proteins are of great importance in many industrial sectors including the textiles, detergent, food, animal feed, cosmetics and medicinal industries as well as in scientific and analytical research [3-8].

Fish processing waste offers a renewable source of these useful enzymes. Extraction of enzymes from fish processing waste may improve the economics of the fish processing industry while minimizing the environmental impact of waste disposal [9-12]. Canada's total seafood and fish landings in the year 2009 were 1,880,896 tons with a total value of 3.3 billion dollars [13]. Annually, about $1,034,492$ tons $(56 \%)$ of fish waste are produced in Canada of which 88,000 - 130,000 metric tons are disposed in the ocean [14].

Collagenase enzymes are one of the protolytic group that cleave the collagen molecule resulting in two triple-helical fragments representing $75 \%$ and $25 \%$ of the intact molecule [15]. Collagenase enzymes have been used in the tannery and fur industries [16], fish processing industries for skinning squid carcasses [11], foodprocessing industry in brewing, clarification and stabilization of beer [12,17-20], medicine [6,21], cosmetics $[7,22]$ production of protein hydrolysates [23], fish silage, fish sauce and fish meal [24-26]. Collagenase is also used in scientific research that relates to animal physiology, especially in removing the connective tissues in neurological studies [27].

These enzymes have been isolated and characterized from microbial cells [28-33] and animal tissues [34-38]. Collagenase enzymes are synthesized as pre-proenzymes and secreted as inactive proenzymes [39-42]. They are classified into two types based on their physiological functions: serine collagenase $[43,44]$ and metallocollagenase $[45,46]$. The molecular weights of collagenase enzymes vary significantly based on the enzyme type. Park et al. [47] reported a collagenase molecular weight of $14.8 \mathrm{kDa}$ from makerel, while Sellers and Murphy [48] and Harris and Vatar [49] reported collagenase molecular weights in the range of $30-150 \mathrm{kDa}$ from mammalian tissues. McCroskery et al. [50] reported collagenase molecular weights in the range of $33-35 \mathrm{kDa}$ from rabbit 
tumor. Other researchers isolated colagenases from marine organisms with molecular weights $<60 \mathrm{kDa}[35,43$, 46].

The aim of this study was to isolate, purify and characterize collagenase enzymes from gut-free fish processing waste materials in order to improve the economics of the fish processing industry and minimize the environmental impact of fish waste disposal. The specific objectives were: (a) to extract, fractionate and purify collagenase from fish processing waste (haddock, herring, ground fish and flounder); (b) to characterize the isolated collagenase based on its molecular mass and (c) to study the effects of ethylenediaminetetraacetic acid (EDTA) concentration $(18.6,27.9$ and $37.2 \mathrm{mg} / \mathrm{mL}$ or 50,75 and $100 \mathrm{mM})$, soybean trypsin $(\mathrm{STI})$ concentration $(5,7.5$ and $10 \mathrm{mg} / \mathrm{mL})$, temperature $\left(20^{\circ} \mathrm{C}-55^{\circ} \mathrm{C}\right)$ and $\mathrm{pH}(5.0-$ $9.0)$ on the collagenase activity.

\section{EXPERIMENTAL MATERIALS}

\subsection{Chemicals}

The chemicals used in this study included: collagen type I (Bovine Achilles Tendon), Tris buffer (hydroxymethylaimnometane), TES (trishydroxymethyl-methyl-2-aminoethan sulfonate), ammonium sulfate, collagenase (Clostridium histolyticum), bovine serum albumin, ethylene glycol monoethyl ether, ninhydrin, stannous chloride, L-leucine, SDS-PAGE electrophoresis reagents, protein molecular weight markers. These were purchased from Fluka Analytical, a Sigma Aldrich Company, Oakville, Ontario, Canada.

\subsection{Fish Waste}

The fish waste (muscles, fins and bones of mixed fish samples of haddock, herring, ground fish and flounder) was obtained from Sea Crest Fisheries Limited, Saulnierville, Nova Scotia, Canada. Samples of $1 \mathrm{~kg}$ were collected in plastic containers and transported to the Food Science and Technology Laboratory at Dalhousie University where they were stored at $-28^{\circ} \mathrm{C}$ until needed.

\section{ENZYME ISOLATION PROCEDURE}

The experimental procedure for isolation of collagenase enzyme included 4 steps: (a) extraction of crude enzymes; (b) fractionation of enzymes; (c) purification of enzymes and (d) activation of enzymes.

\subsection{Extraction of Collagenase Enzyme}

Collagenase enzymes were isolated from the fish waste using the method described by Teruel and Simpson [51] and Hernández-Herrero et al. [52] and summarized in Figure 1. Buffer A ( $50 \mathrm{mM}$ Tris- $\mathrm{HCl}$ buffer containing 5
$\mathrm{mM} \mathrm{CaCl} 2$ with a $\mathrm{pH}$ of 7.4) was added to the fish waste at a ratio of $1: 3(\mathrm{w} / \mathrm{v})$ at $4{ }^{\circ} \mathrm{C}$. The mixture was homogenized using a mixer (DLC-2AC, Cuisinart, Vaughan, Ontario, Canada) at a speed of $7000 \mathrm{rpm}$ with $15 \mathrm{~s}$ mixing intervals and cooling in an ice bath for $30 \mathrm{~s}$ between mixing. The homogenate was centrifuged (IEC-B20A, Fisher Scientific, Pittsburgh, PA, USA) at low speed (5000 rpm) and $4^{\circ} \mathrm{C}$ for 30 minutes and filtered through glass wool (Cat No. 20411, Sigma Aldrich Company, Oakville, Ontario, Canada). The residue was re-extracted using the same procedure and the two supernatants were combined and again filtered through glass wool, followed by filtration through a $0.8 \mu \mathrm{m}$ millipore filter (Cat No. F8398-50EA, Sigma Aldrich Company, Oakville, Ontario, Canada).

\subsection{Fractionation of Collagenase Enzyme}

The crude extract was fractionated using an ammonium sulfate method (Figure 1) similar to that described by Teruel and Simpson [51]. Solid ammonium sulfate was added to the extract solution to a concentration of $40 \%$ and held for one hour at $4{ }^{\circ} \mathrm{C}$. Then the ammonium sulfate concentration was increased to $80 \%$ and held for one hour at $4^{\circ} \mathrm{C}$. The solution was centrifuged at $6750 \mathrm{rpm}$ and $4^{\circ} \mathrm{C}$ for 30 minutes and the pellets were re-suspended in a minimum amount $(1-2 \mathrm{~mL})$ of buffer $\mathrm{A}(50 \mathrm{mM}$ Tris- $\mathrm{HCl}$ buffer containing $5 \mathrm{mM} \mathrm{CaCl}_{2}$ with a $\mathrm{pH}$ of 7.4). The solution was then desalted using a $25 \mathrm{~mm}$ cellulose membrane dialysis tube (Cat No. D9777, Sigma Aldrich Company, Oakville, Ontario, Canada). Ammonium sulfate desalting was carried out three consecutive times. The ammonium sulfate free solution was then centrifuged (IEC-B20A, Fisher Scientific, Pittsburgh, PA, USA) at $6750 \mathrm{rpm}$ and $4^{\circ} \mathrm{C}$ for 30 minutes and the supernatant was collected and stored at $-20^{\circ} \mathrm{C}$.

\subsection{Purification of Collagenase Enzyme}

The biogel chromatography procedure used in this study (Figure 2) was similar to that described by Indra et al. [53] for purification of collagenase enzyme. A Sephadex G-100 column $(1.5 \mathrm{~cm} \times 15 \mathrm{~cm})$ was used. After washing the column with 5 volumes of buffer $A$ at a flow rate 60 $\mathrm{mL} / \mathrm{h}$, and 10 volumes of buffer $\mathrm{B}(50 \mathrm{mM}$ Tris- $\mathrm{HCl}$ buffer containing $5 \mathrm{mM} \mathrm{CaCl}_{2}$ and $0.15 \mathrm{M} \mathrm{NaCl}$ with a $\mathrm{pH}$ of 7.4) at the same flow rate, the supernatant that resulted from the dialysis step (ammonium sulfate free enzyme extract) was loaded into the Sephadex G-100 column at $4^{\circ} \mathrm{C}$. The column was eluted with 10 volumes of buffer $B$ with a flow rate $12 \mathrm{~mL} / \mathrm{h}$. Collagenase enzyme fractions were pooled, freeze dried (FD-ULT-1, Thermovac Industries Corp., Copiague, New York, USA) and stored at $-20^{\circ} \mathrm{C}$. 


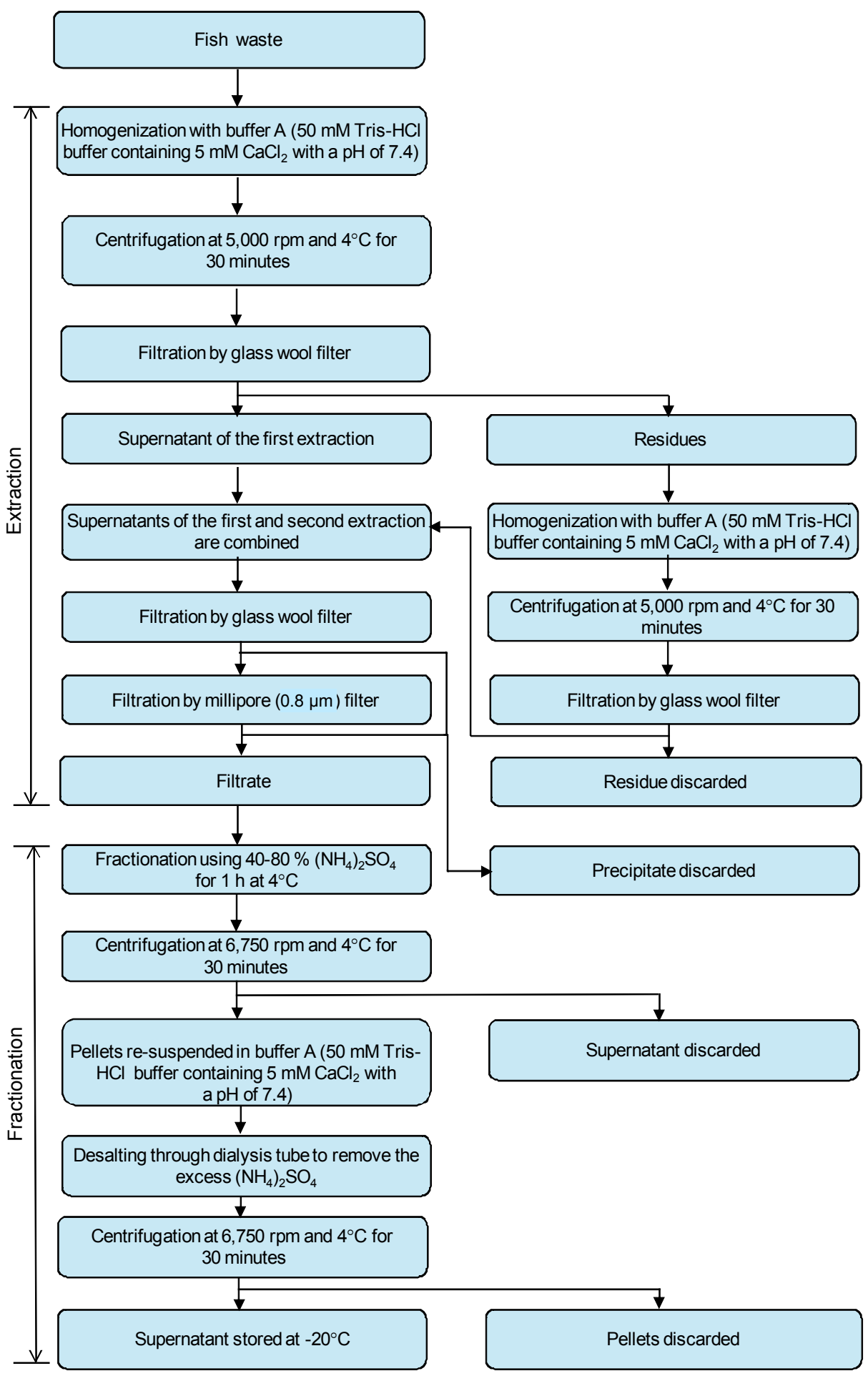

Figure 1. Extraction and fractionation of collagenase enzyme from fish waste.

\subsection{Activation of Procollagenases}

The enzymes in the crude extract, fractionated and purified samples were activated according to the procedure described by Shinkai and Nagai [54] as shown in Figure 3. The enzyme solution $(0.1 \mathrm{~mL})$ was mixed with bovine trypsin $(1 \mu \mathrm{g})$ with a ratio of $1: 1(\mathrm{v}: \mathrm{v})$ and held for 15 minutes at room temperature $\left(\approx 23^{\circ} \mathrm{C}\right)$ followed by addition of soybean trypsin inhibitor ( 5 fold) to stop the proteolysis as recommended by Woessner (1977) and then collagenase activity was assayed. A blank was carried out in which the enzyme solution was treated with the same 


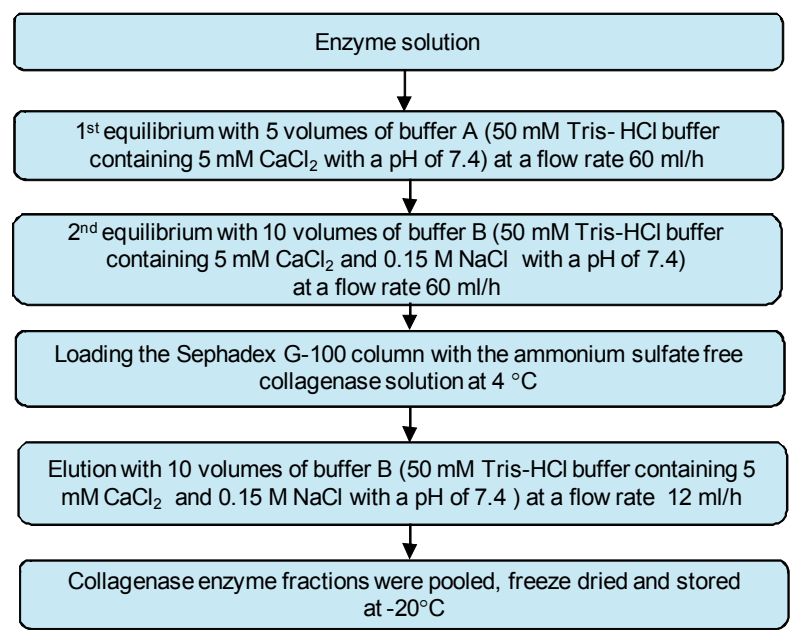

Figure 2. Purification of collagenase enzyme using gel filtration (Sephadex G-100, $1.5 \mathrm{~cm} \times 15 \mathrm{~cm}$ ) at $4^{\circ} \mathrm{C}$.

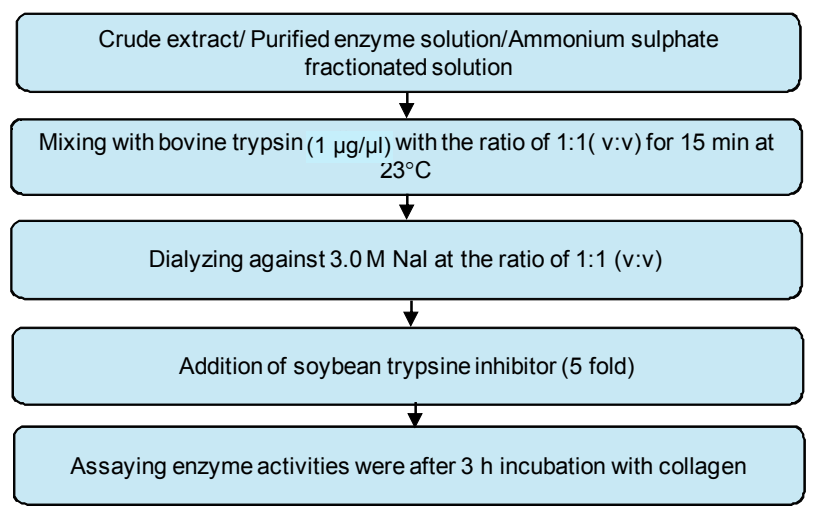

Figure 3. Activation of procollagenase.

manner but without soybean trypsin addition. The enzyme solution was dialyzed against $3.0 \mathrm{M} \mathrm{NaI}$ at the ratio of 1:1 (v:v). The enzyme activities were assayed after 3 hours incubation with collagen and compared to the activities of the non activated enzyme solution.

\section{EFFECTS OF KSCN, INHIBITOR, pH AND TEMPERATURE ON ENZYME ACTIVITIES}

Four separate experiments were carried out to investigate the effects of Potassium thiocyanate (KSCN), inhibitors, temperature and $\mathrm{pH}$ on the enzyme activities.

\subsection{Effect of KSCN Dialysis}

The enzyme in the crude extract was dialyzed against potassium thiocyanate $(\mathrm{KSCN})$ before fractionation with ammonium sulfate according to the procedure described by Woessner [55]. The crude extract was mixed with 6.0 M KSCN in buffer A (50 mM Tris-HCl buffer containing $5 \mathrm{mM} \mathrm{CaCl}_{2}$ with a pH of 7.4). $\mathrm{KSCN}$ was added to the crude extract at a ratio of $1: 5(\mathrm{v} / \mathrm{v})$ and mixed for 30 minutes at $4^{\circ} \mathrm{C}$ in an ice bath using ultrasonic cleaner system (2510R-MTH, Branson Ultrasonic Cleaner, Danbury, USA). This was followed by desalting against the same buffer several times until thiocyanate was not detected. The enzyme then fractionated with ammonium sulfate $(40 \%-80 \%)$ and the ammonium sulfate free super-natant was collected after centrifugation at $6750 \mathrm{rpm}$ and $4^{\circ} \mathrm{C}$ for 30 minutes (IEC-B20A, Fisher Scientific, Pittsburgh, PA, USA) as described by Teruel and Simpson [51]. The enzyme solution was then mixed with substrate and inoculated for 3 hours at $37^{\circ} \mathrm{C}$. The enzyme activity was assayed after incubation and compared with that obtained without addition of KSCN.

\subsection{Effect of Enzyme Inhibitors}

The inhibition effect of ethylenediaminetetraacetic acid (EDTA) with concentrations of 18.6, 27.9 and $37.2 \mathrm{mg} /$ $\mathrm{mL}$ and soybean trypsin (STI) with concentrations of 5 , 7.5 and $10 \mathrm{mg} / \mathrm{mL}$ were tested. The purified enzyme was redissolved in $0.5 \mathrm{~mL}$ buffer A $(50 \mathrm{mM}$ Tris- $\mathrm{HCl}$ buffer containing $5 \mathrm{mM} \mathrm{CaCl}_{2}$ with a $\mathrm{pH}$ of 7.4), mixed with each inhibitor at a ratio of $1: 1(\mathrm{v}: \mathrm{v})$ and incubated for one hour at room temperature $\left(\approx 23^{\circ} \mathrm{C}\right)$, followed by incubation for 3 hours at $37^{\circ} \mathrm{C}$ with collagenase. After incubation, the enzyme activity was assayed and compared to that of the non inhibited enzyme activities.

\subsection{Effect of Temperatures on Collagenase Activity}

To study the effect of temperature, the enzyme solution was preincubated for one hour at the desired temperature $\left(20^{\circ} \mathrm{C}, 25^{\circ} \mathrm{C}, 30^{\circ} \mathrm{C}, 35^{\circ} \mathrm{C}, 40^{\circ} \mathrm{C}, 45^{\circ} \mathrm{C}, 50^{\circ} \mathrm{C}\right.$ or $\left.55^{\circ} \mathrm{C}\right)$ followed by incubating the solution with collagenase for 3 hours at $37^{\circ} \mathrm{C}$. After incubation, the enzyme activity was assayed.

\subsection{Effect of $\mathrm{pH}$ on Collagenase Activity}

To determine the effect of $\mathrm{pH}$ on the enzyme activity, the purified enzyme was redissolved in $0.5 \mathrm{~mL}$ phosphate buffers $(0.05 \mathrm{M})$ solutions with the desired $\mathrm{pH}$ value (5.0, $5.5,6.0$ or 6.5$)$ and in $0.5 \mathrm{~mL}$ buffer A $(50 \mathrm{mM}$ Tris- $\mathrm{HCl}$ buffer containing $5 \mathrm{mM} \mathrm{CaCl}_{2}$ and with desired $\mathrm{pH}$ value $7.0,7.5,8.0,8.5$ or 9.0$)$. The enzyme solutions were incubated at $35^{\circ} \mathrm{C}$ for one hour before mixing with the substrate to stabilize the temperature as recommended by Sivakumar et al. [46] and Indra et al. [54]. It was then incubated with collagenase for 3 hours at $37^{\circ} \mathrm{C}$. After incubation, the enzyme activity was assayed.

\section{EXPERIMENTAL ANALYSES}

\subsection{Determination of Protein Content}

The protein content of the samples was measured using 
bovine serum albumin as protein standard according to the method described by Bradford [56]. Protein solutions were prepared by dissolving bovine serum albumin (Cat. No. A2153, Sigma Aldrich Company, Oakville, Ontario, Canada) in $0.15 \mathrm{M} \mathrm{NaCl}$ to obtain solutions covering the range of $10-100 \mu \mathrm{g}$. The protein reagent was prepared by dissolving $100 \mathrm{mg}$ Coomassie Brilliant Blue G-250 dye (Cat. No. 27815, Sigma Aldrich Company, Oakville, Ontario, Canada) in $50 \mathrm{~mL}$ absolute ethanol (Cat. No. E7023, Sigma Aldrich Company, Oakville, Ontario, Canada) and $100 \mathrm{~mL}$ of $85 \%$ phosphoric acid (Cat. No. P5811, Sigma Aldrich Company, Oakville, Ontario, Canada) were added to the solution and mixed well. The solution was then brought to $1 \mathrm{~L}$ with the addition of deionized water and kept in dark bottles at $4^{\circ} \mathrm{C}$. Exactly 0.1 $\mathrm{mL}$ of the protein solutions, having concentrations of 10 - $100 \mu \mathrm{g}$, was mixed with $5 \mathrm{~mL}$ of the protein solution (Coomassie Brilliant Blue G-250 dye). The absorbance was measured at $595 \mathrm{~nm}$ after two minutes using spectrophotometer (Ultrospec 1100-pro, Amersham Pharmacia Biotech, Piscataway, NJ, USA). A blank containing the protein reagent and $100 \mu \mathrm{l}$ of $0.15 \mathrm{M} \mathrm{NaCl}$ was used to set the zero of the spectrophotometer. Three replicates were carried out and the average protein concentration was plotted against the corresponding absorbance at 595 $\mathrm{nm}$ as shown in Figure 4.

\subsection{Collagenase Total Activity}

The collagenase activity of the samples was assayed using non soluble collagen type I (Bovine Achilles tendon, Cat. No. C9879, Sigma Aldrich Company, Oakville, Ontario, Canada) as the enzyme substrate. One unit of enzyme was defined as the amount which degrades $1 \mu \mathrm{g}$ of collagen per minute at $\mathrm{pH} 7.5$ and $37^{\circ} \mathrm{C}$ [54].

\subsection{Determination of Specific Activity}

The specific activity of the enzyme was expressed as unit/mg protein according to the methods recommended

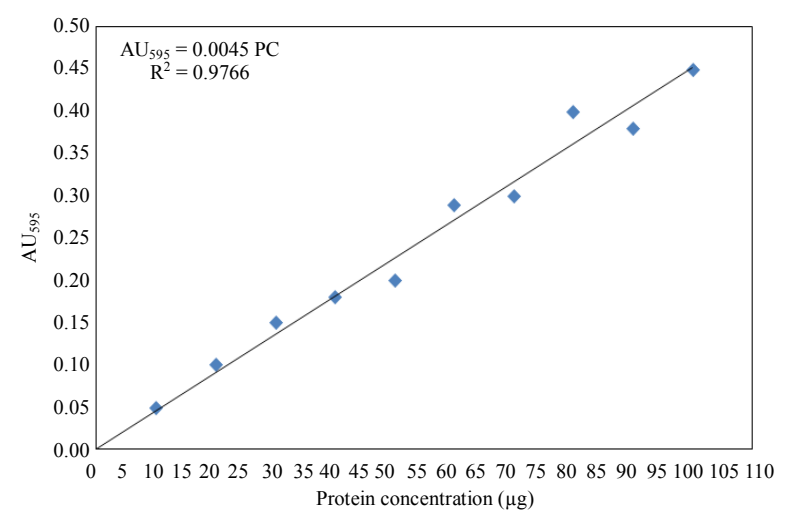

Figure 4. Protien standard curve using bovine serum albu$\min$. by Mandl et al. [57] and Moor and Stein [58]. The released amino acids from collagen after 3 hours incubation at $37^{\circ} \mathrm{C}$ were detected. The liberated amino acids were measured in relation to L-Leucine in the presence of ninhydrine. One unit of collagenase activity was defined as one $\mu \mathrm{mol}$ of L-leucine equivalent librated from substrate over 3 hours of incubation at $37^{\circ} \mathrm{C}$. The L-leucine standard curve was prepared following the methods described by Sigma enzymatic assay (EC 3.4.24.3) of collagenase [59]. A standard solution was prepared by adding 4.0 mM L-leucine (Cat No. L-8000, Sigma Aldrich Company, Oakville, Ontario, Canada) to $10 \mathrm{mM}$ hydrochloric acid solution (Cat No. H-7020, Sigma Aldrich Company, Oakville, Ontario, Canada). A 4\% ninhydrin solution was prepared by dissolving $4.0 \mathrm{~g}$ ninhydrin (Cat. No. N-4876, Sigma Aldrich Company, Oakville, Ontario, Canada) in $100 \mathrm{~mL}$ of ethylene glycol monethyl ether (Cat No. E-2632, Sigma Aldrich Company, Oakville, Ontario, Canada). A citrate buffer solution containing stannous chloride with a $\mathrm{pH}$ of 5.0 was also prepared by dissolving $200 \mathrm{mM}$ anhydrous citric acid free acid (Cat. No. C-0759, Sigma Aldrich Company, Oakville Ontario, Canada) and $0.16 \mathrm{~g}$ anhydrous stannous chloride (Cat. No. S-2752, Sigma Aldrich Company, Oakville, Ontario, Canada) in $100 \mathrm{~mL}$ deionized water and adjusting the $\mathrm{pH}$ to 5 with the addition of $5.0 \mathrm{M}$ $\mathrm{NaOH}$. The ninhydrincolour reagent was prepared by mixing equal volumes of the $4 \%$ ninhydrin solution and citrate buffer solution. Different concentrations of Lleucine covering the range of $5-200 \mu$ l were prepared using deionized water in addition to a blank that did not contain L-leucine. Each sample was mixed with $2.0 \mathrm{~mL}$ of ninhydrine color reagent. The samples were incubated in boiling water for 30 minutes. After cooling at room temperature, $10 \mathrm{~mL}$ of isopropanol (Cat. No. 405-7, Sigma Aldrich Company, Oakville, Ontario, Canada) deionized water solution at a ratio of $1: 1(\mathrm{v} / \mathrm{v})$ were added and mixed well. The absorbance was determined at $570 \mathrm{~nm}$ using spectrophotometer (Ultrospec 1100-pro, Amersham Pharmacia Biotech, Piscataway, NJ, USA). The L-leucine standard curve is shown in Figure 5.

The specific activity was calculated using the following equation.

$$
\mathrm{SA}=\frac{\text { Units } / \mathrm{mL} \text { Enzyme }}{\mathrm{mg} \text { Protein } / \mathrm{mL} \text { Enzyme }}
$$

where:

SA: Specific activity (Units/mg Protein).

\subsection{Determination of Purification Fold (PF)}

The purification fold was used to evaluate the increase in purity of the enzyme after the purification step. It was calculated using the following equation: 


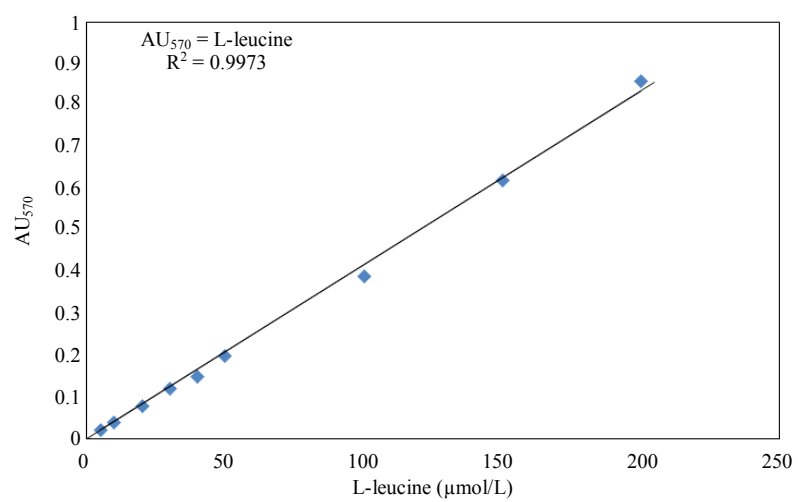

Figure 5. L-leucine solution standard curve.

$$
\mathrm{PF}=\frac{\text { Units } / \mathrm{mg} \text { Purified protein }}{\text { Units } / \mathrm{mg} \text { Crude protein }}
$$

\subsection{Determination of Recovery Yield (RY)}

The recovery yield was defined as the percent of total refined enzyme activity relative to the total crude enzyme activity. It was calculated using the following equation.

$$
\mathrm{RY}=\frac{\text { Units } / \mathrm{mL} \text { Purified protein }}{\text { Units } / \mathrm{mL} \text { Crude protein }} \times 100 \%
$$

\subsection{Estimation of Molecular Weight by SDS-PAGE}

Sodium dodecyl sulphate polyacrylamide gel electrophoresis (SDS-PAGE) was carried out in 5\% - 15\% gradient gels using a vertical gel unit system (LKB 2001, Pharmacia Biotech, Uppsala, Sweden) and power supply unit (LKB BrommaMacrodrive 5-2297 Pharmacia Biotech, Bromma, Sweden) with discontinuous buffer system as recommended by Laemmli [60]. Samples were reduced with mercaptoethanol prior to application. The gels were stained with silver staining (Cat No. 85181, Sigma Aldrich Company, Oakville, Ontario, Canada) according to the procedures described by Wray et al. [61]. The Standards (KDa) used were: myosin 200.00; $\beta$ - glactosidase 116.250; phosphorylase B 97.00; serum albumin 66.00; ovalbumin 45.00; carbonic anhydrase 31.00; soybean trypsin inhibitor 21.00 ; lysozyme 14,400 ; and aprtini 6500 .

\section{RESULTS}

\subsection{Isolation of Collagenase Enzyme}

Crude proteins were first extracted from fish processing waste. The proteins in the crude extract were then precipitated using ammonium sulfate method (40\% - 80\%) and the enzyme in the ammonium sulfate free solution was purified using Sephadex G-100 chromatographic technique. The total enzyme activity, specific activity, purification fold and recovery yield were determined for each sample. The results are presented in Table 1.

The protein content in the crude enzyme was $2.33 \pm$ $0.10 \mathrm{mg} / \mathrm{L}$. It decreased to $1.33 \pm 0.10 \mathrm{mg} / \mathrm{L}(57.08 \%)$ after fractionation with ammonium sulfate and then to $0.95 \pm 0.04 \mathrm{mg} / \mathrm{L}(40.77 \%)$ after desalting (removal of ammonium sulfate). The final protein content after purification using biogel chromatography was $0.034 \pm 0.03$ $\mathrm{mg} / \mathrm{L}(1.46 \%)$.

The total activity of the crude enzyme was $27.10 \pm$ $4.80 \mathrm{unit} / \mathrm{mL}$ which decreased to $21.85 \pm 3.04 \mathrm{unit} / \mathrm{mL}$ $(80.86 \%)$ and then to $18.49 \pm 1.10 \mathrm{unit} / \mathrm{mL}(68.23 \%)$ after fractionation with ammonium sulfate and desalting, respectively. Purification with biogel chromatography decreased the total activity to a final value of $6.17 \pm 0.20$ unit/mL (22.77\%).

The specific activity of the crude enzyme was $11.63 \pm$ $2.14 \mathrm{unit} / \mathrm{mg}$. It increased to $16.43 \pm 3.19 \mathrm{unit} / \mathrm{mg}$ $(141.27 \%)$ and then to $19.46 \pm 1.42 \mathrm{unit} / \mathrm{mg}(167.33 \%)$ after fractionation with ammonium sulfate and desalting, respectively. The final value of the specific activity after purification with biogel chromatography was $181.47 \pm$ $3.82 \mathrm{unit} / \mathrm{mg}(1560.36 \%)$.

The purification fold of the crude enzyme was 1.00, which then increased to $1.42,1.66$ and 15.70 after fractionation with ammonium sulfate, desalting and purification with biogel chromatography, respectively.

\begin{tabular}{|c|c|c|c|c|c|}
\hline \multirow{2}{*}{ Purification step } & \multirow{2}{*}{ Total protein $(\mathrm{mg} / \mathrm{mL})$} & \multicolumn{2}{|c|}{ Enzyme activities } & \multirow{2}{*}{ Purification fold (-) } & \multirow{2}{*}{ Recovery yield (\%) } \\
\hline & & Total (Unit/mL) & Specific (Unit/mg) & & \\
\hline Curd enzyme & $2.33 \pm 0.10$ & $27.10 \pm 4.80^{\mathrm{a}}$ & $11.63 \pm 2.14$ & 1.00 & 100.00 \\
\hline $\begin{array}{l}\text { After fractionation with } \\
\text { ammonium sulfate }(40 \%-80 \%)\end{array}$ & $1.33 \pm 0.10$ & $21.85 \pm 3.04^{\mathrm{a}}$ & $16.43 \pm 3.19$ & 1.42 & 80.63 \\
\hline Ammonium sulfate free solution & $0.95 \pm 0.04$ & $18.49 \pm 1.10^{\mathrm{a}}$ & $19.46 \pm 1.42$ & 1.66 & 68.24 \\
\hline $\begin{array}{l}\text { After purification with } \\
\text { sephadex G-100 }\end{array}$ & $0.034 \pm 0.03$ & $6.17 \pm 0.20^{\mathrm{b}}$ & $181.47 \pm 3.82^{b}$ & 15.70 & 22.77 \\
\hline
\end{tabular}

Table 1. Change in extraction parameters of collagenase enzyme.

Values are average of three replicates $($ Mean \pm SD). 
The recovery yield of crude enzyme (100\%) was reduced to $80.63 \%$ and $68.84 \%$ after the fractionation and desalting steps, respectively. A final recovery yield of $22.77 \%$ was achieved after purification with biogel chromatography.

The relationship between protein concentration and the total and specific activities are shown in Figure 6. The results showed that the higher the protein concentration, the higher the total activity and the lower the specific activity. The high protein content observed before purification was due to the presence of other proteins which resulted in lower specific activity. The fractions recovered after 3 hours from Bio-Gel column chromatography on Sephadex G-100 showed a specific activity value of $181.47 \pm 3.82 \mathrm{unit} / \mathrm{mg}$ protein and recovery yield of $22.77 \%$. Increasing the purification time beyond 3 hours significantly reduced the collagenase activity as shown in Figure 7. On the other hand, 1 and 2 hour of incubation time of the purification step also resulted in much lowerspecific activities (4 and 18 unit $/ \mathrm{mg}$, respectively).

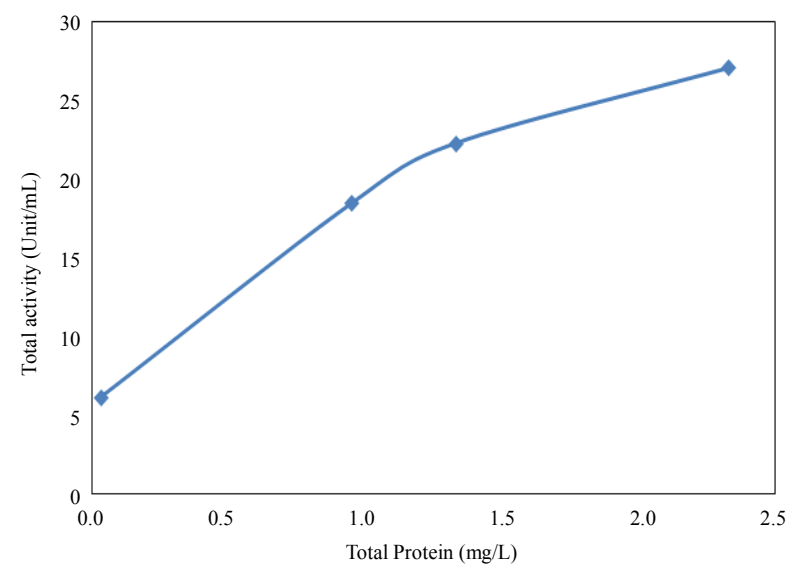

(a)

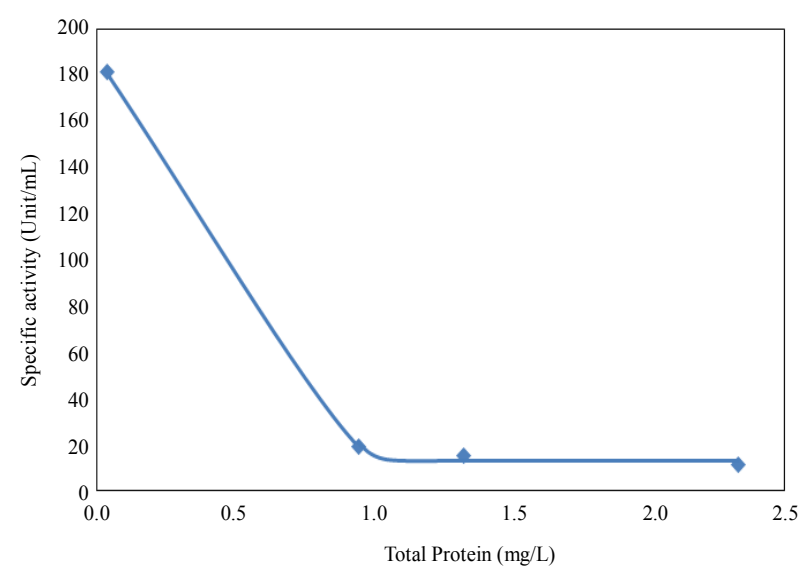

(b)

Figure 6. Effect of protein content on total and specific enzyme activities. (a) Total activity; (b) Specific enzyme activities.

\subsection{Activation of the Collagenase Enzyme}

The results of collagenase enzyme activities are shown in Table 2. The enzyme total and specific activities were significantly affected by the addition of KSCN. The collagenase total activity was reduced from $10.95 \pm 0.83$ to $5.4 \pm 0.19 \mathrm{unit} / \mathrm{mL}(145.44 \%)$ and the specific activity increased from $6.25 \pm 0.19$ to $9.09 \pm 1.08 \mathrm{unit} / \mathrm{mg}$ protein $(80.68 \%)$ by the addition of $\mathrm{KSCN}$. The enzyme solution mixed with the bovine trypsin $(1 \mu \mathrm{g} / \mu \mathrm{L})$ recorded a total activity of $21.28 \pm 1.17 \mathrm{unit} / \mathrm{mL}$ and a specific activity of $40.36 \pm 13.92$ unit $/ \mathrm{mg}$ protein. When the enzyme solution was mixed with the soybean trypsin inhibitor, a total activity of $13.75 \pm 0.32 \mathrm{unit} / \mathrm{mL}$ and a specific activity of $27.18 \pm 1.04 \mathrm{unit} / \mathrm{mg}$ protein were observed.

On the other hand, direct mixing of the enzyme solution with $3.0 \mathrm{M} \mathrm{NaI}$ or dialysis against the same concentration of NaI did not show any effect on activity.

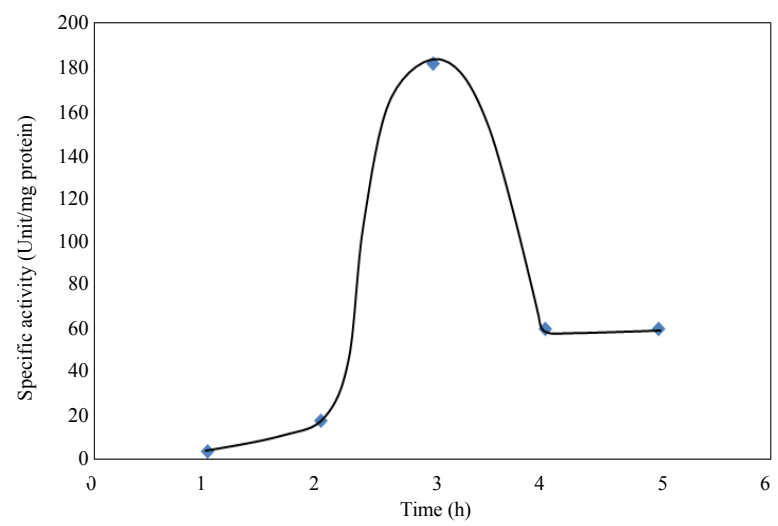

Figure 7. Effect of incubation time on the specific activity during activation.

Table 2. Effect of some activators on the collagenase activities.

\begin{tabular}{cccc}
\hline Activation processes & $\begin{array}{c}\text { Total activity } \\
\text { (unit/mL) }\end{array}$ & $\begin{array}{c}\text { Specific activity } \\
\text { (unit/mg protein) }\end{array}$ & $\begin{array}{c}\text { Activity } \\
(\%)\end{array}$ \\
\hline $\begin{array}{c}\text { Extracted collagenase } \\
\text { enzyme }\end{array}$ & $10.95 \pm 0.83$ & $6.25 \pm 0.19$ & 100.00 \\
$\begin{array}{c}\text { Potassium } \\
\text { thiocyanate }\end{array}$ & $5.4 \pm 0.19$ & $9.09 \pm 1.08$ & 18.20 \\
$\begin{array}{c}\text { Bovine trypsin } \\
(1 \mu \mathrm{g} / \mathrm{mL})^{\mathrm{I}}\end{array}$ & $21.28 \pm 1.17$ & $40.36 \pm 3.92$ & 424.51 \\
$\begin{array}{c}\text { Bovine trypsin } \\
(1 \mu \mathrm{g} / \mathrm{mL})^{\mathrm{II}}\end{array}$ & $13.75 \pm 0.32$ & $27.18 \pm 1.04$ & 253.25 \\
$\begin{array}{c}\text { Dialysis against } \\
3.0 \mathrm{M} \mathrm{NaI}\end{array}$ & $\mathrm{ND}$ & $\mathrm{ND}$ & $\mathrm{ND}$ \\
$\begin{array}{c}\text { Mixing with } \\
3.0 \mathrm{M} \mathrm{NaI}(\mathrm{v} / \mathrm{v})\end{array}$ & $\mathrm{ND}$ & $\mathrm{ND}$ & $\mathrm{ND}$ \\
\hline
\end{tabular}

The values are average of three replicates (mean value $\pm \mathrm{SD}$ ); ${ }^{\mathrm{I}}$ Enzyme solution mixed with soybean trypsin inhibitor after activation; "II Enzyme solution was not mixed with soybean trypsin inhibitor; ND: no detectable activity. 


\subsection{Effect of Enzyme Inhibitors}

Table 3 shows the inhibitory effects of ethylenediaminetetraacetic acid (EDTA) and soybean trypsin inhibitor (STI) on collagenase activity. A complete inhibition $(100 \%)$ occurred with all EDTA concentrations and with STI concentrations of 10 and $7.5 \mathrm{mg} / \mathrm{mL}$. The concentration of $5 \mathrm{mg} / \mathrm{mL}$ of STI reduced the total activity from $10.95 \pm 1.44 \mathrm{unit} / \mathrm{mL}$ to $2.78 \pm 0.88 \mathrm{unit} / \mathrm{mL}(73.31 \%$ reduction) and the specific activity from $6.25 \pm 0.11$ to $2.07 \pm 0.30 \mathrm{unit} / \mathrm{mg}$ protein $(66.88 \%$ reduction $)$.

\subsection{Effect of Temperatures}

Collagenase enzyme isolated from fish waste materials showed low activities at extreme temperatures of $20^{\circ} \mathrm{C}$ and $55^{\circ} \mathrm{C}$. Only $38 \%$ and $8 \%$ of the activity were observed at $20^{\circ} \mathrm{C}$ and $55^{\circ} \mathrm{C}$, respectively. Optimum collagenase activity $(100 \%)$ was recorded at $35^{\circ} \mathrm{C}$ (Figure 8).

\subsection{Effect of pH}

Collagenase enzyme isolated from the fish waste materials showed increased activity with increased $\mathrm{pH}$ with an optimum activity recorded at a $\mathrm{pH}$ 7.5. A sharp decrease in activity was observed when the $\mathrm{pH}$ was further increased and only $10 \%$ of the activity was recorded at $\mathrm{pH}$ of 9 (Figure 9).

\subsection{Molecular Weights}

The St lane (protein molecular weights markers) has nine bands with molecular weights between 200.0 and 6.5 $\mathrm{kDa}$. The collagenase enzyme isolated from ammonium sulfate fractionation (Lane 1) showed seven bands of protein with molecular weights varying from 55.0 to 6.5

Table 3. Effect of inhibitors on the collagenase enzyme activity.

\begin{tabular}{|c|c|c|c|}
\hline \multirow[b]{2}{*}{ Sample } & \multicolumn{2}{|c|}{ Collagenase activities } & \multirow{2}{*}{$\begin{array}{c}\text { Inhibition } \\
(\%)\end{array}$} \\
\hline & $\begin{array}{c}\text { Total } \\
\text { (Unit/mL) }\end{array}$ & $\begin{array}{c}\text { Specific } \\
\text { (Unit/mg protein) }\end{array}$ & \\
\hline $\begin{array}{l}\text { Non inhibited } \\
\text { collagenas }\end{array}$ & $10.95 \pm 1.44^{\mathrm{a}}$ & $6.25 \pm 0.11^{\mathrm{a}}$ & 0.00 \\
\hline \multicolumn{4}{|l|}{ EDTA $(\mathrm{mg} / \mathrm{mL})$} \\
\hline 18.6 & ND & ND & 100.00 \\
\hline 27.9 & ND & ND & 100.00 \\
\hline 37.2 & ND & ND & 100.00 \\
\hline \multicolumn{4}{|l|}{$\mathrm{STI}(\mathrm{mg} / \mathrm{mL})$} \\
\hline 5.0 & $2.78 \pm 0.88^{\mathrm{b}}$ & $2.07 \pm 0.30^{\mathrm{b}}$ & 73.31 \\
\hline 7.5 & ND & ND & 100.00 \\
\hline 10.0 & ND & ND & 100.00 \\
\hline
\end{tabular}

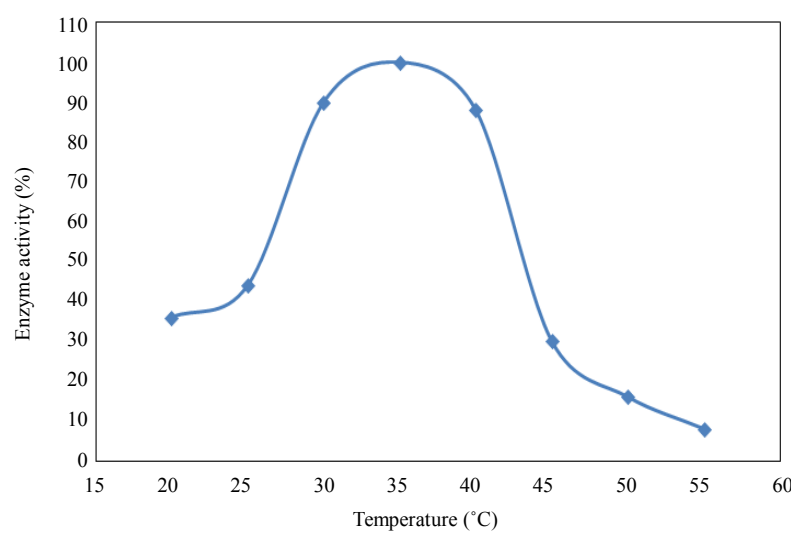

Figure 8. Effect of temperatures on activity of the collage-nase enzyme.

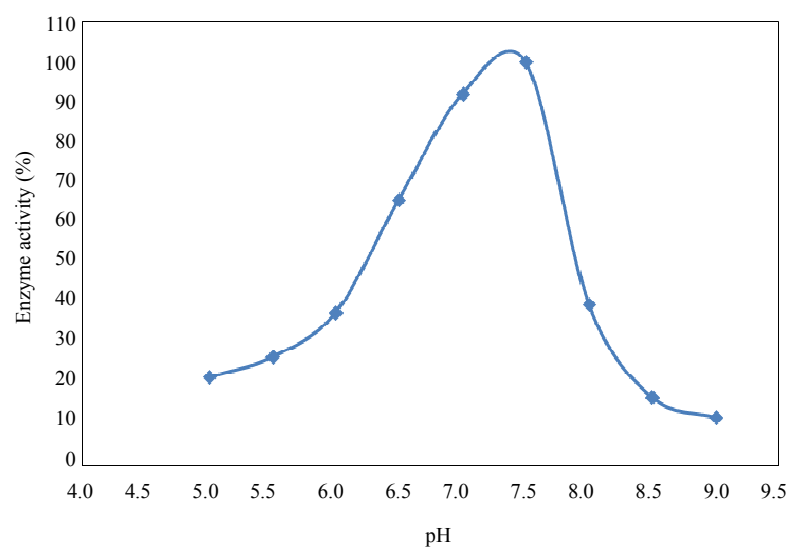

Figure 9. Effect of $\mathrm{pH}$ on the activity of collagenase enzyme.

$\mathrm{kDa}$ (Figure 10). The ammonium sulphate free solution (Lane 2) showed five protein bands with molecular weights between 55.0 and $6.5 \mathrm{kDa}$. The purification process using Biogel Chromatography (Lane 3) reduced the protein impurities in the enzyme solution to one band with a molecular weight of $50.0 \mathrm{kDa}$. NaI treatment (Lane 4) showed no activation or shift in the molecular weight as compared with the purification step (Lane 3). The enzyme solution eluted from the Biogel column after one hour (Lane 5) showed six protein bands with molecular weights varying from $200.0 \mathrm{kDa}$ to $6.5 \mathrm{kDa}$ representing protein impurities in addition to collagenase. The activated collagenase with bovine trypsin (Lane 6) showed two bands: a large one with a molecular weight of $50.0 \mathrm{kDa}$ and a small one with a molecular weight $10.0 \mathrm{kDa}$. The enzyme solution activated with potassium thiocyanate (Lane 7) showed one protein band with a molecular weight of $50.0 \mathrm{kDa}$.

\section{DISCUSSION}

In the present study, the extraction, purification and assay of collagenase enzyme from fish waste as well as the 


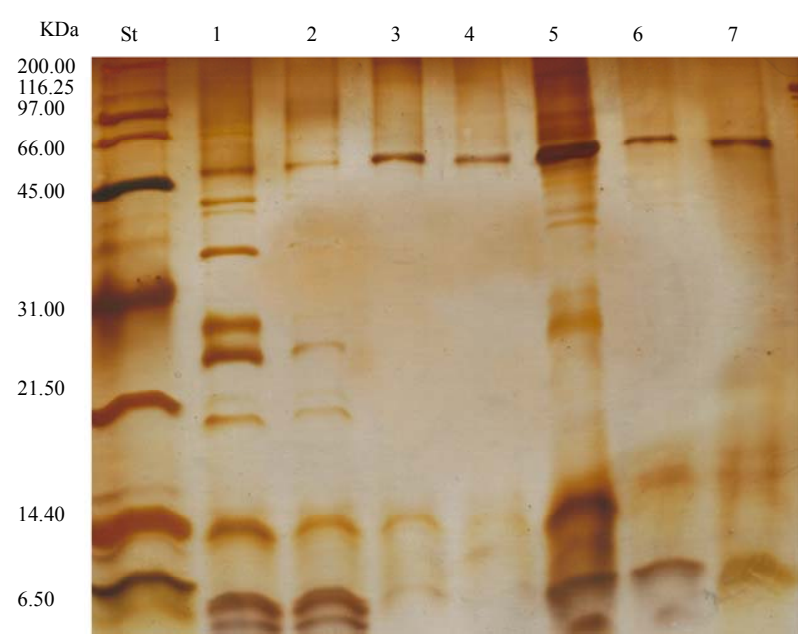

Figure 10. The molecular weights $(\mathrm{kDa})$ of enzyme solutions $(\mathrm{St}=$ protein molecular weight markers, $1=$ ammonium sulfate fractionated enzyme solution, $2=$ ammonium sulfate free enzyme solution, 3 = purified enzyme, $4=$ activated enzyme with NaI, $5=$ fractions after one hour of Sephadex G-100, $6=$ activated with bovine trypsin and $7=$ activated enzyme by potassium thiocyanate).

effect of several inhibitors, temperature and $\mathrm{pH}$ on collagenase activities were illustrated. Animal collagenases especially those isolated from crustacean have the ability to breakdown collagens $[34,35,62]$. Several researchers reported that the collagenase enzymes are secreted in an inactive form and can be activated by trypsin or other proteases $[63,64]$ or by dialysis against $3.0 \mathrm{M}$ sodium thiocyanate $(\mathrm{NaSCN})$ [65]. The activity of collagenase enzyme isolated from the fish waste in the present work using insoluble bovinecollagen as substrate was low during the first 2 hours incubation and an optimum activity was obtained after 3 hours of inoculation.

In the present study, collagenase activity in the crude extract was not detected neither by dialysis against $3.0 \mathrm{M}$ sodium iodide (NaI) nor by mixing with $3.0 \mathrm{M} \mathrm{NaI}$ solution. These results were unexpected, as Shinkai and Nagai [54] reported that $\mathrm{NaI}$ treatment increases the collagenolytic activities. However, activation of the collagenase was achieved by direct incubation with $6.0 \mathrm{M}$ potassium thiocaynate (KSCN) with the enzyme solution. It appears that when the procollagenase was combined with $\mathrm{KSCN}$ the $\alpha$-macroglobulin was partly dissociated releasing the active collagenase form $[54,65,66]$.

When the enzyme was treated with bovine trypsin, the enzyme activity increased and to 3 times greater than the non activated enzyme. That was attributed to the proteolysis effect of trypsin which converted the latent enzyme that persisted into an activated form $[67,68]$. Trypsin also prevents inhibition of collagenase by binding with $\alpha$-2-macroglobulin which is known to inhibit mammalin collagenase and other proteases $[39,54,69,70]$.
The purified collagenase was inhibited by all the three concentrations of EDTA indicating that the metal ions are required to activate the enzyme by metalloprotease [46, 54]. Soybean trypsin inhibitor (STI) with concentrations of 10 and $7.5 \mathrm{mg} / \mathrm{mL}$ inhibited the activity of the collagenase enzyme completely. It has been reported that STI inhibited the collageolytic enzymes from cod, shrimp, catfish and krill [71-74], indicating that enzyme have a trypsin-like property [75].

Collagenase enzymes reported by many researchers have a wide range of molecular weights. This wide range of molecular weights is to be expected with an enzyme such as collagenase that does not have a single structure nor a single source $[13,35,40,43,46,47,49,50,76,77]$. SDS-PAGE indicated that the purified procollagenase treated with trypsin consisted of two subunits with molecular weights $50.0 \mathrm{KDa}$ and $10.0 \mathrm{KDa}$ suggesting that procollagenase could be dissociated into the active form during the electrophoresis process. The low molecular weight molecule could be the results of proteolytic degradation of the protein that was produced as a result of trypsin action [78].

The results showed that temperature had a significant effect on collagenase enzyme activities. The highest value was recorded at temperatures between $30^{\circ} \mathrm{C}$ and $40^{\circ} \mathrm{C}$ with the maximum activity recorded at $35^{\circ} \mathrm{C}$. On the other hand, higher temperature (above $50^{\circ} \mathrm{C}$ ) resulted in denaturation of the enzyme, as very little activity was observed at this higher temperature. This may be due to the unfolding of the enzyme molecule which resulted in thermal inactivation [37].

Collagenase enzyme isolated from the fish waste showed activities correlated to $\mathrm{pH}$ when $\mathrm{pH}$ was near to the physiological $\mathrm{pH}$ of most animal spices at 7.5 [43]. Collagense activities recorded a maximum value at $\mathrm{pH}$ 7.5 here and decreased with $\mathrm{pH}$ values above or below that value. The reduction in enzyme activities at acidic or alkaline $\mathrm{pH}$ may be related to the change of the enzyme structure and/or its active sites due to decreasing electrostatic bonds [79]. Omondi and Stark [80] and Sriket et al. [37] found that the collagolytic and proteolytic activities of crude protease isolated from fish and shellfish showed the optimum activities at $\mathrm{pH}$ values of 6.5 to 8.0. However, the effect of acidic or alkaline $\mathrm{pH}$ on the collagenase is similar to those of all proteinases that have been isolated from fish species [35,81-85].

\section{CONCLUSION}

The present work illustrated the usefulness of the fish processing waste as a source for value added enzymes such as collagenase enzyme. Isolation of collagenase from fish processing waste will have a positive impact on the economics of the fish processing industry and will 
minimize the environmental impact of current fish waste disposal. Tris-buffer extraction was found to be an easy, safe and cost effective method for the recovery of collagenase enzyme. The proteins in the crude extract were first precipitated using ammonium sulfate $(40 \%-80 \%)$ and then purified with gel-filtration chromatography using Sephadex G-100. The collagenase enzyme was activated with bovine trypsin and potassium thiocyanate (KSCN). The activity of the enzyme recovered from fish processing waste (haddock, herring, ground fish, flounder) was affected by the $\mathrm{pH}$ and temperature with the maximum activity observed at $\mathrm{pH} 7.5$ and $35^{\circ} \mathrm{C}$. The addition of KSCN decreased the enzyme total activity and increased its specific activity. The enzyme activity was completely inhibited by the action of ethylenediaminetetraacetic acid (EDTA) suggesting that the collagenase enzyme isolated from the fish waste is a metalloproteinase enzyme requiring metal ions for enzyme activity. Collagenase enzyme isolated in this work had a molecular weight of two subunits with one of $50 \mathrm{kDa}$ and the other of $10 \mathrm{kDa}$.

\section{ACKNOWLEDGEMENTS}

This research was supported by the National Science and Engineering Research Council (NSERC) of Canada through a Strategic Grant.

\section{REFERENCES}

[1] Simpson, B.K. and Haard, N.F. (1987) Trypsin and a trypsin-like enzyme from the stomachlesscunner. Catalytic and other physical characteristics. Journal of Agriculture and Food Chemistry, 35, 652-656.

[2] Liese, A., Seelbach, K. and Wandrey, C. (2006) Advantages of biotransformations over classical chemistry enzymes are proteins. In: Industrial Biotransformations, WileyVchverlagGmbh and Co. KGaA, Weinheim.

[3] Cronlund, A.L. and Woychik, J.H. (1987) Solubilization of collagen in restructured beef with collagenases and $\alpha$-Amylase. Journal of Food Science, 52, 857-860. doi:10.1111/j.1365-2621.1987.tb14227.x

[4] Ågren, M.S., Taplin, C.J., Woessner, J.F. Jr., Eagistein, W.H. and Mertz, P.M. (1992). Collagenase in wound healing: Effect of wound age and type. Journal of Investigative Dermatology, 99, 709-714. doi:10.1111/1523-1747.ep12614202

[5] Ashie, I.N.A. and Lanier, T.C. (2000) Transglutaminases in seafood processing. In: Haard, N.F. and Simpson, B.K. Eds., Seafood Enzymes Utilization and Influence on Postharvest Seafood Quality, Marcel Dekker, Inc., New York.

[6] Püllen. R., Popp, R., Volkers, P. and Füsgen, I. (2002) Prospective randomized double-blind study of the wounddebriding effects of collagenase and fibrinolysin/deoxyribonuclease in pressure ulcers. Age and Ageing, 31, 126130. doi:10.1093/ageing/31.2.126

[7] Mohorcic, M., Friedrich, J., Renime, I., Andre, P., Mandin,
D. and Chaumont, J.P. (2006) Production of melanin bleaching enzyme of fungal origin and its application in cosmetics. Biotechnology and Bioprocess Engineering, 12, 200-206. doi:10.1007/BF02931093

[8] Kanth, S.V., Venba, R., Madhan, B., Chandrababu, N.K. and Sadulla, S. (2008). Studies on the influence of bacterial collagenase in leather dyeing. Dyes and Pigments, 76, 338-347. doi:10.1016/j.dyepig.2006.08.043

[9] Raa, J. (1997) New commercial products from waste of the fish processing industry. In: Bremner, A., Davis, C. and Austin, B., Eds., Making the Most of the Catch, Proceedings of the Seafood Symposium, Brisbane.

[10] Haard, N.F. (1998) Speciality enzymes from marine organisms. Food Technology, 52, 64-67.

[11] Venugopal, V., Lakshmanan, R., Doke, S.N. and Bongirwar, D.R. (2000) Enzymes in fish processing, biosensors and quality control: A review. Food Biotechnology, 14, 21-27. doi:10.1080/08905430009549980

[12] Shahidi, F. and Janak Kamil, Y.V.A. (2001) Enzymes from fish and aquatic invertebrates and their application in the food industry. Trends in Food Science and Technology, 12, 435-464. doi:10.1016/S0924-2244(02)00021-3

[13] DFO (2012) Summary of Canadian commercial catches and values, 2008-2009. Commercial Fisheries, Department of Fisheries and Oceans Canada, Ottawa. http://www.dfo-mpo.gc.ca/stats/commercial/land-debarq/ sum/sum0809-eng.htm

[14] Roberts, T. (2010) Alternatives are not feasible, producers say, fish waste dumping continues. http://www.souwester.ca/News/2010-04-01/article-98373 4/Fish-waste-dumping-continues/1

[15] Nagai, Y. (1973) Vertebrate collagenase: Further characterization and the significance of its latent form in vivo. Molecular and Cellular Biochemistry, 1, 137-145. doi:10.1007/BF01659325

[16] Goshev, I., Gousterova, A., Vasileva-Tonkova, E. and Nedkov, P. (2005) Characterization of the enzyme complexes produced by two newly isolated thermophylicactinomycete strains during growth on collagen-rich materials. Process Biochemistry, 40, 1627-1631. doi:10.1016/j.procbio.2004.06.016

[17] Foegeding, E.A. and Larick, D.K. (1986) Tenderization of beef with bacterial collagenase. Meat Science, 18, 201214. doi:10.1016/0309-1740(86)90034-3

[18] Dĩaz-López, M. and García-Carreńo, F.L. (2000) Applications of fish and shellfish enzymes in food and feed products. In: Haard, N.F. and Simpson, B.K., Eds., Seafood Enzymes, Utilization and Influence on Postharvest Seafood Quality, Marcel Dekker, New York.

[19] Gupta, R., Beg, Q.K., Khan, S. and Chauhan, B. (2002) An overview on fermentation, downstream processing and properties of microbial alkaline proteases. Applied Microbiology and Biotechnology, 60, 381-395. doi:10.1007/s00253-002-1142-1

[20] Shanmugam, S. and Sathishkumar, T. (2009) Enzyme technology. International Publishing House PVT, New Delhi. 
[21] Chung, L., Dinakarpandian, D., Yoshida, N., Lauer-Fields, J.L., Fields, G.B., Visse, R. and Nagase, H. (2004) Collagenase unwinds triple-helical collagen prior to peptide bond hydrolysis. The European Molecular Biology Organization Journal, 23, 3020-3030.

[22] Spök, A. (2006) Safety regulations of food enzymes. Food Technology and Biotechnology, 44, 197-209.

[23] Kristinsson, H.G. and Rasco, B.A. (2000) Fish protein hydrolysates: Production, biochemical and functional properties. Critical Reviews in Food Science and Nutrition, 40, 43-81. doi:10.1080/10408690091189266

[24] Glidberg, A. (2001) Utilization of male Arctic capelin and Atlantic cod intestines for fish sauce production evaluation of fermentation conditions. Bioresource Technology, 769, 119123. doi:10.1016/S0960-8524(00)00095-X

[25] Shih, I.L., Chenb, L.G., Yu, T.S., Changb, W.T. and Wang, S.L. (2003) Microbial reclamation of fish processing wastes for the production of fish sauce. Enzyme and Microbial Technology, 33, 154-162. doi:10.1016/S0141-0229(03)00083-8

[26] Tao, H., Zhao, M.M., Wang, J.S., Yang, B., Cui, C., Zhao, Q.Z. and $\mathrm{Wu}, \mathrm{H}$. (2008) Activity distribution of digestive proteases from Nemipterusvirgatus and their responses to $\mathrm{pH}$ value and temperature. Journal of Food Processing Engineering, 31, 21-33. doi:10.1111/j.1745-4530.2007.00141.x

[27] Klöck, G., Kowalski, M.B., Hering, B.J., Eiden, M.E., Weidemann, A., Langer, S., Zimmermann, U., Federlin, K. and Bretzel, R.G. (1996) Fractions from commercial collagenase preparations: Use in enzymic isolation of the islets of Langerhans from porcine pancreas. Cell Transplantation, 5, 543-551. doi:10.1016/0963-6897(96)00023-1

[28] Mookhtiar, K., Steinbrink, S.D. and Van Wart, H.E. (1985) Mode of hydrolysis of collagen-like peptidase by class I and class II Clostridium histolyticum collagenases: Evidence for both indopeptidase and tripeptidylcarboxypeptidase activities. Biochemistry, 24, 6527-6533. doi:10.1021/bi00344a033

[29] Goldberg, G.I., Wilhelm, S.M., Kronberger, A., Bauer, E.A., Grant, G.A. and Eisen, A.Z. (1986) Human fibroblast collagenase. Complete primary structure and homology to an oncogene transformation-induced rat protein. The Journal of Biological Chemistry, 261, 6600-6605.

[30] Endo, A., Murakawa, S., Shimizu, H. and Shiraishi, Y. (1987) Purification and properties of collagenase from a Streptomyces species. The Journal of Biochemistry, 102, 163-170.

[31] Lim, D.V., Jackson, R.J. and Pull-VonGruenigen, C.M. (1993) Purification and assay of bacterial collagenase. Journal of Microbiological Methods, 18, 241-253. doi:10.1016/0167-7012(93)90039-K

[32] Matsushita, O., Yoshihara, K., Katayama, S.I., Minami, J. and Okabe, A. (1994) Purification and characterization of a Clostridium perfringes 120-Kilodalton collagenase and nucleotide sequence of the corresponding gene. Journal of Bacteriology, 176, 149-156.

[33] Wu, Q., Li, C., Chen, H. and Shuliang, L. (2009) Purification and characterization of a novel collagenase from
Bacillus pumilus Col-J. Applied Journal of Biochemistry and Biotechnology, 160, 129-139.

[34] Garcia-Carreno, F.L., Hernandez-Cortes, M.P. and Haard, N.F. (1994) Enzymes with peptidase and proteinase activity from the digestive system of a freshwater and marine decapod. Journal of Agricultural and Food Chemistry, 42, 1456-1461. doi:10.1021/jf00043a013

[35] Kristjánsson, M.M., Gudmundsdóttir, S., Fox, J.W. and Bjarnason, J.B. (1995) Characterization of collagenolytic serine proreinase from the Atlantic cod (Gadusmorhua). Comparative Biochemistry and Physiology, Part B, 110, 707-717.

[36] Vaithilingam, I.S., McDonald, W., Malott, D.W. and Del Maestro, R.F. (1995) An extracellular proteasome-like structure from C6 astrocytoma cells with serine collagenase IV activity and metallo-dependent activity on $\alpha$ casein and $\beta$-insuline. The Journal of Biological Chemistry, 270, 4588-4593.

[37] Sriket, C., Benjakul, S., Visessanguan, W. and Kishimura, H. (2011) Collagenolytic serine protease in fresh water prawn (Macrobrachiumrosenbergii): Characteristics and its impact on muscle during iced storage. Food Chemistry, 124, 29-35. doi:10.1016/j.foodchem.2010.05.098

[38] Murado, M.A., González, M.P. and Vázquez, J.A. (2009) Recovery of proteolytic and collagenolytic activities from viscera by-products of Rayfish (Raja clavata). Marine Drugs, 7, 803-815. doi:10.3390/md7040803

[39] Birkedal-Hansen, H., Cobb, C.M., Taylor, R.E. and Fullmer, H.M. (1975) Trypsin activation of latent collagenase from several mammalian sources. European Journal of Oral Sciences, 83, 302-305. doi:10.1111/j.1600-0722.1975.tb00442.x

[40] Sellers, A. and Murphy, G. (1981) Collagenolytic enzymes and their naturally occurring inhibitors. International Review of Connective Tissue Research, 9, 151-190.

[41] Armour, P.C., Levi, S., Golds, E.E., Poole, A.R., Mort, J.S. and Roughley, P.J. (1984) Activation of latent collagenase by serum proteinases that interact with immobilized immunoglobulin G. Rheumatology International, 4, 151-155. doi:10.1007/BF00541205

[42] He, C., Wilhelm, S.M., Pentland, A.P., Marmer, B.L., Grant, G.A., Eisen, A.Z. and Goldberg, G.I. (1989) Tissue cooperation in a proteolytic cascade activating human interstitial collagenase. Proceeding of the National Academy of Science, 86, 2632-2636.

[43] Roy, P., Bernard, C. and Patrick, D. (1996) Purification, kinetical and molecular characterizations of a serine collagenolytic protease from green shore Crab (Carcinusmaenas) digestive gland. Comparative Biochemistry and Physiology, Part B, 115, 87-95.

[44] Zefirova, O.N., Mamaeva, A.V., Chupov, V.V., Valuev, L.I. and Plate, N.A. (1996) Synthesis and properties of immobilized collagenolytic protease from hepatopancreas of the king crab Paralithoidescamtschatica. Applied Biochemistry and Microbiology, 32, 461-464.

[45] Freije, J.P., Diez-Itza, I., Balbin, M., Sanchez, L.M., Blasco, R., Tolivia, J. and Lopez-Otin, C. (1994) Molecular cloning and expression of collagenase-3, a novel human matrix metalloproteinase produced by breast car- 
cinomas. The Journal of Biological Chemistry, 269, 1676616773.

[46] Sivakumar, P., Sampath, P. and Chandrakasan, G. (1999) Collagenolytic metalloprotease (gelatinase) from the hepatopancreas of the marine crab Scylla serrata. Comparative Biochemistry and Physiology, Part B, 123, 273-279.

[47] Park, P.J., Lee, S.H., Byun, H.G., Kim, S.H. and Kim, S.K. (2002) Purification and characterization of a collagenase from the Mackerel, Scomberjaponicus. Journal of Biochemistry and Molecular Biology, 35, 576-582. doi:10.5483/BMBRep.2002.35.6.576

[48] Sellers, A. and Murphy, G. (1981) Collagenolytic enzymes and their naturally occurring inhibitors. International Review of Connective Tissue Research, 9, 151-190.

[49] Harris, E.D. and Vatar, C.A. (1982) Vertebrate collagenases. Methods Enzymology, Part A, 82, 423-452.

[50] McCroskery, P.A., Richards, J.F. and Harris, E.D.J. (1975) Purification and characterization of a collagenase extracted from rabbit tumours. Biochemical Journal, 152, 131-142.

[51] Teruel, S.R.L. and Simpson, B.K. (1995) Characterization of the collagenolytic enzyme fraction from winter flounder (Pseudopleuronectes americanus). Compendium of Biochemistry and Physiology, Part B, 112, 131-136.

[52] Hernández-Herrero, M.M., Duflos, G., Malle, P. and Bouquelet, S. (2003) Collagenase activity and protein hydrolysis as related to spoilage of iced cod (Gadusmorhua). Food Research International, 36, 141-147. doi:10.1016/S0963-9969(02)00129-1

[53] Indra, D., Ramalingam, K. and Babu, M. (2005) Isolation, purification and characterization of collagenase from heaptopancreas of the land snail Achatinafulica. Comparative Biochemistry and Physiology, Part B, 142, 1-7.

[54] Shinkai, H. and Nagai, Y. (1977) A latent collagenase from embryonic human skin explants. The Journal of Biochemistry, 81, 1261-1268.

[55] Woessner, J.F. Jr. (1977) A latent form of collagenase in the involuting rat uterus and its activation by a serine proteinase. Biochemical Journal, 161, 535-542.

[56] Bradford, M.M. (1976) A rapid and sensitive method for the quantitation of microgram quantities of protein utilizing the principle of protein-dye binding. Analytical Biochemistry, 72, 248-254. doi:10.1016/0003-2697(76)90527-3

[57] Mandl, I., MacLennan, J.D., Howes, E.L., DeBellis, R.H. and Sohler, A. (1953) Isolation and characterization of proteinase and collagenase from C. histolyticum. Journal of Clinical Investigation, 32, 1323-1329. doi:10.1172/JCI102861

[58] Moor, S. and Stein, W. (1954) A modified ninhydrin reagent for the photometric determination of amino acids and related compounds. Journal of Biochemistry, 211, 907913.

[59] Sigma-Aldrich (1996) Enzymatic assay of collagenase1 (EC 3.4.24.3)-collagen digestion assay. http://www.sigmaaldrich.com/etc/medialib/docs/Sigma/E nzyme_Assay/collagenaseddig.Par.0001.File.tmp/collage naseddig.pdf
[60] Laemmli, U.K. (1970) Cleavage of structural proteins during the assembly of the head of bacteriophage T4. Nature, 227, 680-685. doi:10.1038/227680a0

[61] Wray, W., Boulikas, T., Wray, V.P. and Hancock, R. (1981) Sliver staining of proteins in polyacrylamide gels. Analytical Biochemistry, 118, 197-203. doi:10.1016/0003-2697(81)90179-2

[62] Eisen, A.Z., Henderson, K.O., Jeffrey, J.J. and Bradshaw, R.A. (1973) A collagenolytic protease from the hepatopancreas of the fiddler crab, Ucapugilator. Purification and properties. Biochemistry, 12, 1814-1822. doi:10.1021/bi00733a024

[63] Bauer, E.A., Stricklm, G.P., Jeffrey, J.J. and Eisen, A.Z. (1975) Collagenase production by human skin fibroblasts. Biochemical and Biophysical Research Communications, 64, 232-240. doi:10.1016/0006-291X(75)90243-0

[64] Vaes, G. and Eeckhout, Y. (1975) In dynamics of connective tissue macromolecules. North-Holland Publishing Company, Amsterdam-Oxford.

[65] Abe, S. and Nagai, Y. (1972) Interaction between tadpole collagenase and human $\alpha_{2}$-macroglobluin. BiochimicaetBiophysica Acta, 278, 125-132.

[66] Ohyama, H. and Hashimoto, K. (1977) Collagenase of human skin basal cell epithelioma. Biochemistry, 82, 175183.

[67] Vaes, G. (1972) The release of collagenase as an inactive proenzyme by bone explants in culture. Biochemical Journal, 126, 275-289.

[68] Shinkai, H., Kawamoto, T., Hori, H. and Nagai, Y. (1977) A complex of collagenase with low molecular weight inhibitors in the culture medium of embryonic chick skin explants. Journal of Biochemistry, 81, 261-263.

[69] Sakamoto, S., Goldhaber, P. and Glimcher, M.J. (1972) The further purification and characterization of mouse bone collagenase. Calcified Tissiue Research, 10, 142-151. doi:10.1007/BF02012544

[70] Woessner, J.F. Jr. (1991) Matrix metalloproteinases and their inhibitors in connective tissue remodeling. The FASEB Journal, 5, 2145-2154.

[71] Grant, G.A., Henderson, K.O., Eisen, A.Z. and Bradshaw, R.A. (1980) Amino acid sequence of a collagenolytic protease from the hepatopancreas of the fiddler crab, Ucapugilator. Biochemistry, 19, 4653-4659. doi:10.1021/bi00561a018

[72] Yoshinaka, R., Sato, M., Itoko, M., Yamashita, M. and Ikeda, S. (1986) Purification and characterization of a collagenolytic serine proteinase from the catfish pancreas. Journal of Biochemistry, 99, 459-467.

[73] Turkiewicz, M., Galas, E. and Kalinowska, H. (1991) Collagenolytic serine proteinase from Euphasiasuperbadana (Antarctic krill). Comparative Biochemistry and Physiology, Part B, 99, 359-371.

[74] Tsai, I.H., Lu, P.J. and Chuang, J.L. (1991). The midgutchymotrypsins of shrimps (Penaeusmonodon, Penaeusjaponicus and Penaeuspenicillatus). Biochimicaet Biophysica Acta, 1080, 59-67. doi:10.1016/0167-4838(91)90112-D

[75] Werner, M.H. and Wemmer, D.E. (1991) 1H assignments and secondary structure determination of the soy- 
bean trypsin/chymotrypsin Bowman-Birk inhibitor. Biochemistry, 30, 3356-3364. doi:10.1021/bi00228a002

[76] Fiedler-Nagy, C., Coffey, J.W. and Salvador, R.A. (1977) Factors influencing the apparent molecular weight of collagenase produced by human-skin explants. European Journal of Biochemistry, 76, 291-297. doi:10.1111/j.1432-1033.1977.tb11595.x

[77] Ozaki, I., Zhao, G., Mizuta, T., Ogawa, Y., Hara, T., Kajihara, S., Hisatomi, A., Sakai, T. and Yamamoto, K. (2002) Hepatocyte growth factor induces collagenase (matrix metalloproteinase-1) via the transcription factor Ets-1 in human hepatic stellate cell line. Journal of Hepatology, 36, 169-178. doi:10.1016/S0168-8278(01)00245-8

[78] Murphy, G., Reynolds, J.J., Bretz, U. and Baggiolini, M. (1982) Partial purification of collagenase and gelatinase from human polymorphonuclear leucocytes. Biochemical Journal, 203, 209-221.

[79] Vojdani, F. (1996) Solubility. In: Hall, G.M. Ed., Methods of Testing Protein Functionality, Chapman and Hall, New York. doi:10.1007/978-1-4613-1219-2 2

[80] Omondi, J.G. and Stark, J.R. (2001) Studies on digestive proteases from midgut glands of a shrimp, Penaeusindicus, and a lobster, Nephropsnorvegicus: Part 1. Prote- olytic activity. Applied Biochemistry and Biotechnology, 90, 137-153. doi:10.1385/ABAB:90:2:137

[81] Ăsgeirsson, B., Fox, J.W. and Bjarnason J.B. (1989) Purification and characterization of trypsin from the poikilotherm Gadusmorhua. European Journal of Biochemistry, 180, 85-94. doi:10.1111/j.1432-1033.1989.tb14618.x

[82] Ăsgeirsson, B. and Bjarnason, J.B. (1991) Structural and kinetic properties of chymotrypsin from Atlantic cod (Gadusmorhua). Comparison with bovine chymotrypsin. Comparative Biochemistry and Physiology, 99, 327-335.

[83] Ăsgeirsson, B. and Bjarnason, J.B. (1993) Properties of elastase from Atlantic cod a cold-adapted proteinase. Biochimicaet Biophysica Acta-Protein Structure and Molecular Enzymology, 1164, 91-100.

[84] Kristjánsson, M.M. (1991) Purification and characterization of trypsin from the pyloric caeca of rainbow trout (Oncorhynchusmykiss). Journal of Agriculture and Food Chemistry, 39, 1738-1742. doi:10.1021/jf00010a009

[85] Kristjánsson, M.M. and Nielsen, H.H. (1992) Purification and characterization of two chymotrypsin-like proteases from the pyloric caeca of rainbow trout (Oncorhynchusmykiss). Comparative Biochemistry and Physiology, 101, 247-253. 